\title{
Performance of an agricultural engine using blends of diesel and ethanol
}

\author{
Desempenho de um motor agrícola utilizando misturas de óleo diesel e etanol
}

\author{
Javier Solis Estrada ${ }^{I^{*}}$ José Fernando Schlosser ${ }^{\mathrm{II}}$ Marcelo Silveira de Farias ${ }^{\mathrm{I}}$ \\ Fabrício Azevedo Rodrigues ${ }^{I}$ Alfran Tellechea Martini ${ }^{I}$ Gustavo Oliveira dos Santos ${ }^{I}$
}

\section{ABSTRACT}

This research evaluated the performance of a diesel engine in an agricultural tractor, using Diesel S500 (B5) and mixture with 3\% (ED3), 6\% (ED6), 9\% (ED9), 12\% (ED12) and $15 \%$ (ED15) of hydrous ethanol. Variables evaluated were the power, torque, specific fuel consumption, torque reserve, speed reserve and elasticity index of engine. Results indicated that using B5 and ED3 the values of torque and engine power not differ, in addition, with the ED3 the fuel consumption was lower than $5.92 \%$. Using ED12, power has reduced in $2.97 \%$, compared with B5, while their fuel consumption had no difference. With ED15, the power was lower $6.30 \%$ and the fuel consumption increase $3.77 \%$, both compared with B5. Torque reserve value was increased with increasing the ethanol content in B5, reducing the speed reserve and elasticity index of engine. Ethanol in Diesel S500 (B5) can be used as an alternative fuel in agricultural tractor engines without presenting high changes in the performance, since the ethanol content is at low percentages, up to $12 \%$.

Key words: biofuel, diesel cycle, agricultural tractor, brake dynamometer.

\section{RESUMO}

Neste trabalho, foi avaliado o desempenho de um motor ciclo Diesel de um trator agrícola, utilizando óleo Diesel S500 (B5) e sua mistura com 3\% (ED3), 6\% (ED6), 9\% (ED9), $12 \%$ (ED12) e 15\% (ED15) de etanol hidratado. As variáveis estudadas foram: potencia, torque, consumo especifico de combustivel, reserva de torque, reserva de rotação e índice de elasticidade do motor. Os resultados indicam que, utilizando B5 e ED3, os valores de torque e potência do motor não diferiram, além disso, com o ED3, o consumo de combustivel foi $5,92 \%$ menor. Utilizando ED12, a potência, em relação ao B5, teve uma redução de 2,97\%, sem diferença para o consumo de combustivel. Já com o ED15, a potência diminuiu 6,30\% e o consumo aumentou $3,77 \%$, em comparação com o B5. Os valores de reserva de torque foram incrementados conforme aumentou o conteúdo de etanol, reduzindo a reserva de rotação e o índice de elasticidade do motor. A mistura de etanol no óleo Diesel B5 pode ser utilizada como combustivel alternativo em motores agrícolas, sem apresentar alterações significativas no seu desempenho, desde que seja utilizado até $12 \%$ de etanol.

Palavras-chave: biocombustivel, ciclo Diesel, trator agrícola, freio dinamométrico.

\section{INTRODUCTION}

Due to the increasing demand for energy, it is clear that the non-renewable reserves are faded to run out over time. The highest power consumption of the world comes from oil and its derivatives (AGARWAL, 2007). Also according to the author, the use of biofuels seeks to reduce dependence on oil, providing more options to users at the scarcity of petroleum based fuels.

Among the proposals of alternative fuels, the addition of ethanol in diesel oil has gained attention, being its use in diesel cycle engines stimulated (HANSEN et al., 2005). The use of ethanol, besides reducing dependence on fossil fuel, would help to reduce emissions of greenhouse gases in the cycle diesel engine (RAHIMI, 2009).

IPrograma de Pós-graduação em Engenharia Agrícola (PPGEA), Universidade Federal de Santa Maria (UFSM), 97105-900, Santa Maria, RS, Brasil. E-mail: j.solis.estrada@gmail.com. "Corresponding author.

IIDepartamento de Engenharia Rural (DER), Centro de Ciências Rurais (CCR), Universidade Federal de Santa Maria (UFSM), Santa Maria, RS, Brasil. 
The addition of ethanol in diesel oil causes in the latter physical and chemical changes, noticeable reduction in cetane number, viscosity, and flash point (LI et al., 2005). These modifications change the characteristics of the fuel jet injected into the cylinder, the quality of combustion, and emissions of pollutants from the engine.

Such unwanted changes are minimized with the addition of emulsifiers or co-solvents, making the mixture homogeneous, improving its physical and chemical properties (LAPUERTA et al., 2007). Accordingly, biodiesel has been used as an additive to improve the solubility of ethanol in diesel oil (RIBEIRO et al., 2007).

In some countries, the blends of ethanoldiesel are already marketed (ED) as fuel. In Thailand, it is used $10 \%$ ethanol in diesel oil, and in Australia, Sweden, and the USA, mixtures with $15 \%$ ethanol are used (HANSEN et al., 2005). Regarding the addition of ethanol in diesel oil, SHADIDI et al. (2014) stated that it can be added up to $15 \%$ ethanol without the need for mechanical changes in the engine.

Some research indicated that the use of ED mixtures change the performance of the cycle diesel engine, causing variations in the power and specific fuel consumption. By adding ethanol in diesel fuel, the power and the engine torque decrease and fuel consumption increases as a consequence of lower calorific value, cetane number, and delay in the injection point (RAHIMI et al., 2009).

In this sense, the main goal of this study was to determine the power, torque, specific fuel consumption, torque reserve, speed reserve and elasticity index of an agricultural engine using as fuel diesel oil S500 (B5) and its mixture with 3\% (ED3),
6\% (ED6), 9\% (ED9), 12\% (ED12), and 15\% (ED15) of hydrated ethanol.

\section{MATERIALS AND METHODS}

Diesel oil was used S500 (B5) and hydrous ethanol from sugarcane, as fuels, and its physicochemical properties shown on table 1. ED mixtures were conducted at the site of the experiment. The volumetric densities of the six fuels used B5, ED3, ED6, ED9, ED12, and ED15 are: 845, 844, $843,840,838$ and $837 \mathrm{~kg} \mathrm{~m}^{-3}$, respectively, at $19.5^{\circ} \mathrm{C}$ to room temperature.

The experiment was carried out using a tractor Massey Ferguson brand, model MF 4291, equipped with a four-cylinder Perkins engine 1104A-44T, 4.4 L of displaced volume, supercharged by turbocharger with power and maximum torque of $77,2 \mathrm{~kW}$ and $400 \mathrm{Nm}$, according to information from the manufacturer under the ISO standard 14396. Engine fuel injection pump is a mechanical rotary one, Delphi brand.

Before starting the evaluations, the engine was heated for 20 minutes. For this purpose, the throttle was positioned at full speed, using an electric dynamometer EGGERS, model PT 301 MES, and a load was applied to reduce the engine speed until the nominal. In addition, at each fuel change, the engine was left running under load, so that residues of the previous fuel in the injection system could be consumed by the engine. The schematic representation of the experiment is shown in figure 1 .

With the same dynamometer used to warm the engine, dynamometer experiments were performed to determine the torque $(\mathrm{Nm})$ and calculate the power $(\mathrm{kW})$ of the engine as a function of speed. In order to

Table 1 - Physical-chemical properties of the fuels used in the experiment.

\begin{tabular}{lll}
\hline & \multicolumn{1}{c}{ Dieseloil (B5) S500* } & Ethanol \\
\hline $\mathrm{Ph}$ & - & $6.0-8.0$ \\
Fusion point-Freeze & $-40-6{ }^{\circ} \mathrm{C}$ & $-117^{\circ} \mathrm{C}$ \\
Initial boiling pointand boiling $\mathrm{T}^{\mathrm{o}}$ range & $150-471{ }^{\circ} \mathrm{C}$ & $77^{\circ} \mathrm{C}$ \\
Flash point & $38^{\circ} \mathrm{C}$ & $15^{\circ} \mathrm{C}(\mathrm{closed} \mathrm{vessel)}$ \\
Vapourpressure & $0.4 \mathrm{kPa}$ at $40{ }^{\circ} \mathrm{C}$ & $5.8 \mathrm{kPa}$ at $20{ }^{\circ} \mathrm{C}$ \\
Specificmass & $0.820-0.865$ at $20^{\circ} \mathrm{C}$ & $0.8\left(\right.$ water at $\left.4{ }^{\circ} \mathrm{C}=1\right)$ \\
Auto-ignition $\mathrm{T}^{\mathrm{o}}$ & $=225^{\circ} \mathrm{C}$ & $363^{\circ} \mathrm{C}$ \\
Decomposition T & $400^{\circ} \mathrm{C}$ & - \\
Viscosity & $2.5 \times 10^{-5}-5 \times 10^{-5} \mathrm{~m}^{2} \mathrm{~s}^{-1} \mathrm{a} 40^{\circ} \mathrm{C}$ & $1.20 \times 10^{-3} \mathrm{P} . \mathrm{s} \mathrm{a} 20^{\circ} \mathrm{C}$ \\
\hline
\end{tabular}

${ }^{*}$ With $5 \%$ of biodiesel.

Source: Petrobras. 


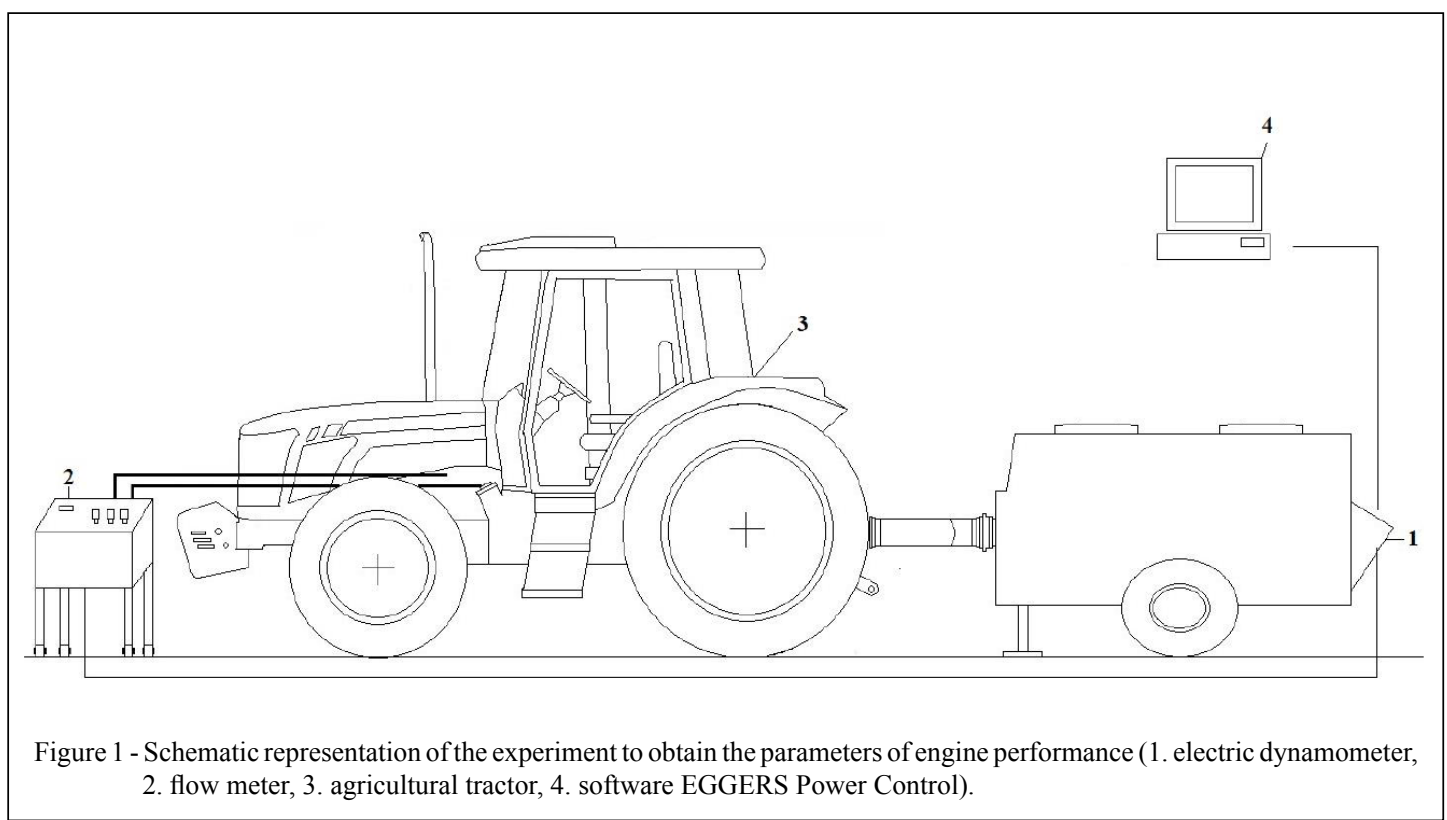

determine the fuel specific consumption - SFC $\left(\mathrm{gkWh}^{-1}\right)$ of the engine, it was used an EGGERS flow meter, model FM3-100. Other variables calculated for each fuel used were: torque reserve $(\Delta \mathrm{M})$, speed reserve (R.r.), and the elasticity index (E.I.) of the engine.

Due to the fact that measurements were performed on tractor PTO, a loss by transmission of the engine was considered to a PTO of $8 \%$ (MÁRQUEZ, 2012). The correction of power obtained by the dynamometer was carried out according to DIN 70020 (1986), by software EGGERS Power Control that manages the use of the dynamometer and the flow meter.

Dynamometer experiments were performed in the range of 2300 to $1100 \mathrm{rpm}$, collecting the performance values every 100rpm. Analyses of results were made in engine speed range from 2100 to $1400 \mathrm{rpm}$, where the speed torque and maximum power are, for all fuels used.

Torque, power, and fuel specific consumption of the engine were analyzed according to a factorial scheme (6x8), from the interaction of six types of fuel and the eight engine speeds analyzed. Three replicates were performed, thus composing a completely randomized design experiment. Statistical analysis was done applying the Tukey test at 5\% error probability. For this, it was used the Sisvar software, version 5.3.

\section{RESULTS AND DISCUSSION}

Figure 2a shows the engine power curves in relation to the speeds. In this figure, it is observed that with the addition of ethanol to B5, there is a tendency of decreasing power as the ethanol content increases. According to RAHIMI et al. (2009), using ED mixtures in a diesel cycle engine, a reduce performance, indicating that the addition of oxygenates in diesel oil reduces engine power. Other studies concluded that the lower stability, density, calorific value, and the higher water content of the mixture ED contribute to the reduction of engine power (TORRES-JIMENEZ et al., 2011; LAPUERTA et al., 2007).

Also in figure $2 \mathrm{a}$, it was found that for all the fuels used, the maximum power is achieved at 2100 engine rpm. In this revolution, the highest values were obtained with the engine using ED3, B5, and ED6, where maximum power values were $76.07 ; 75.92$, and $75.46 \mathrm{~kW}$, respectively. ED9, ED12, and ED15 showed a reduction of the maximum power of $3.32 ; 3.74$, and $7.53 \%$, respectively, compared to $\mathrm{B} 5$.

Considering the eight speeds analyzed, it can be seen in table 2 that for the variable power the best result was obtained using B5, which did not differ from ED3. Moreover, it is observed that up to ED6 the decrease of the engine power was less than $1 \%$, in relation to $\mathrm{B} 5$. These results can be explained by the presence of biodiesel in the diesel oil S500 (B5), which acts as an additive, stabilizing the ED mixture and improving its physical and chemical properties (KWANCHAREON et al., 2007; LAPUERTA et al., 2009). 


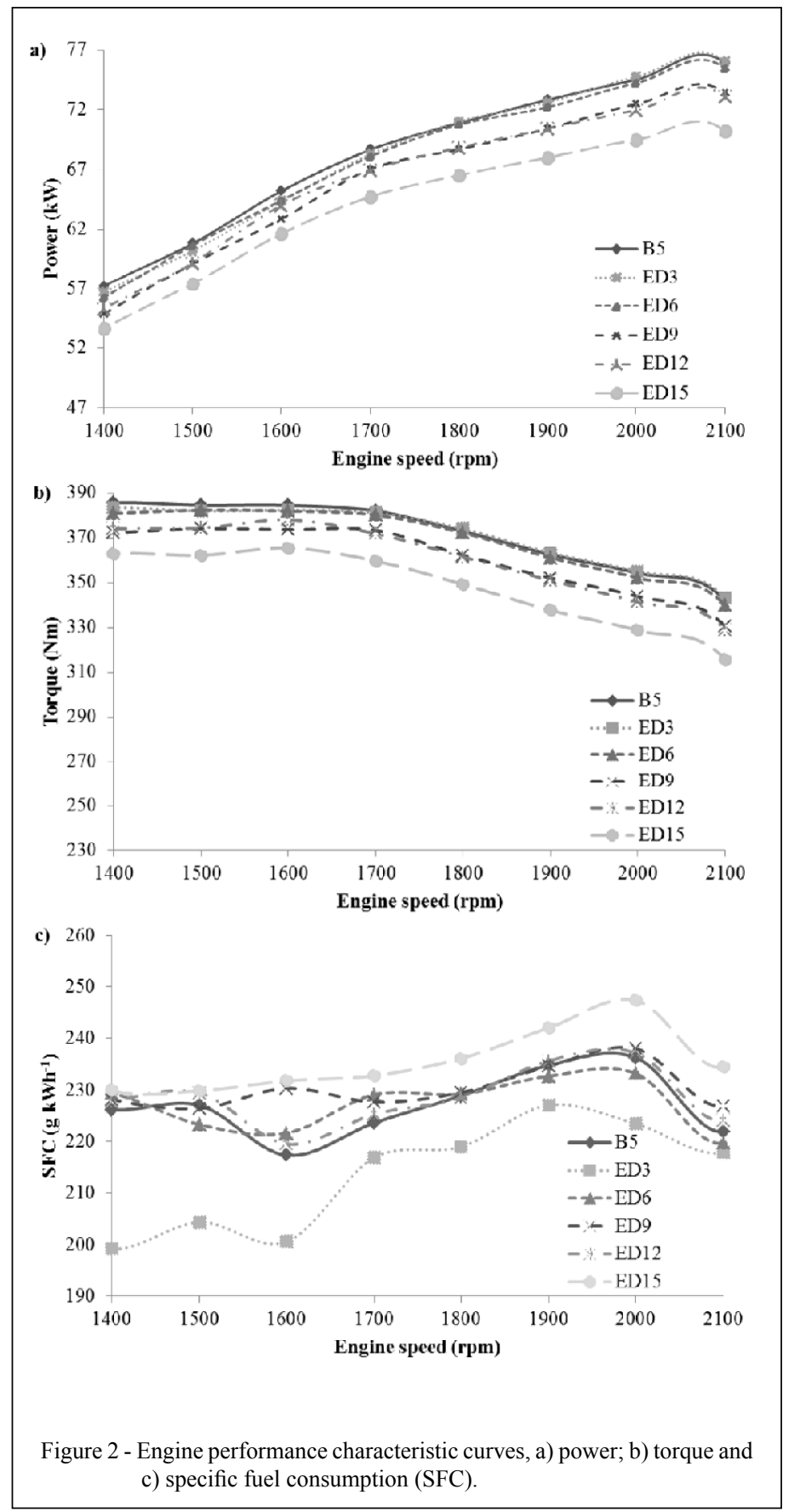

It is also observed in table 2 that when the engine used ED12 and ED15, it had a power loss of 2.97 and $6.30 \%$, respectively, when compared to B5. In similar researches, using ED15, HANSEN et al. (2005) and KASS et al. (2001) reported that the power decreased from 7 to $10 \%$ compared with the diesel oil.

For variable torque, it is feasible to see in figure $2 b$ that the maximum values were found in three different engine speeds, according to the fuel used. As it increased the percentage of ethanol in B5, the maximum torque speed is greater, being $1400 \mathrm{rpm}$ for B5 (385.56 $\mathrm{Nm})$ and ED3 (383.40 Nm); $1500 \mathrm{rpm}$ for ED6 (382.32 $\mathrm{Nm})$ and ED9 $(374.04 \mathrm{Nm})$, and $1600 \mathrm{rpm}$ for the ED12 $(378.00 \mathrm{Nm})$ and ED15 (365.40 Nm).

The differences found in the maximum torque speed are related to the stoichiometric

Ciência Rural, v.46, n.7, jul, 2016. 
Table 2 - Average values of the variables of engine performance and their variation $(\Delta)$, with respect to the B5.

\begin{tabular}{|c|c|c|c|c|c|c|}
\hline Comb. & Power $^{*}(\mathrm{~kW})$ & $\Delta(\%)$ & Torque $^{*}(\mathrm{Nm})$ & $\Delta(\%)$ & $\mathrm{SFC}^{*}\left(\mathrm{~g} \mathrm{kWh}^{-1}\right)$ & $\Delta(\%)$ \\
\hline B5 & $68.25 \pm 0.18 \mathrm{a}$ & 0.00 & $371.03 \pm 0.74 \mathrm{a}$ & 0.00 & $226,97 \pm 1.94 b$ & 0.00 \\
\hline ED3 & $68.00 \pm 0.14 \mathrm{ab}$ & -0.37 & $370.53 \pm 0.55 \mathrm{a}$ & -0.13 & $213.53 \pm 11.74 \mathrm{c}$ & -5.92 \\
\hline ED6 & $67.75 \pm 0.05 b$ & -0.73 & $368.82 \pm 0.47 b$ & -0.59 & $227.27 \pm 1.29 b$ & 0.13 \\
\hline ED12 & $66.22 \pm 0.19 \mathrm{c}$ & -2.97 & $360.09 \pm 0.64 c$ & -2.91 & $228.41 \pm 1.44 b$ & 0.63 \\
\hline ED9 & $66.11 \pm 0.28 \mathrm{c}$ & -3.14 & $360.23 \pm 1,73 c$ & -2.95 & $230.20 \pm 0.91 \mathrm{ab}$ & 1.42 \\
\hline ED15 & $63.95 \pm 0.01 \mathrm{~d}$ & -6.30 & $347.67 \pm 0.41 \mathrm{~d}$ & -6.29 & $235.54 \pm 0.32 \mathrm{a}$ & 3.77 \\
\hline
\end{tabular}

*Means followed by the same letter in the column do not differ by the Tukey test at $5 \%$ error probability.

ratio of the fuel, since the addition of ethanol to B5 increases the oxygen levels in the combustion. It is possible to state that the maximum torque of speeds had the best ratio of consumption of air/fuel according to the mixture used.

In table 2, for torque, it appears that the average values using B5 and ED3 did not differ. Using ED12, the torque was $2.91 \%$ lower $(10.80 \mathrm{Nm})$ in relation to B5. ED15 had a reduction of $6.29 \%(23.36$ $\mathrm{Nm})$. Reduction in values can be explained by the lower cetane number and calorific value of ethanol compared to diesel oil, which affects the quality of injection and combustion. According to CHEN et al. (2009), the cetane number of the mixture ED decreases linearly with increasing percentages of ethanol.

For the engine torque reserve (Table 3), it is clear that its value increases as the percentage of ethanol is higher. By using the ED15, values were increased $23.55 \%$ as compared to the value obtained with the B5 (12.74\%). Also in this table, it is observed that the speed of the engine reserve and elasticity index were increased as the percentage of ethanol decreased. According MÁRQUEZ (2012), the average value for the speed reservation in agricultural tractors is $33.8 \%$.

Table 3 - Average values of the variables: torque reserve $(\Delta M)$, speed reserve (R.r.) and elasticity index (E.I.) of the engine.

\begin{tabular}{llll}
\hline Fuels & $\Delta \mathrm{M}(\%)$ & R.r. $(\%)$ & E.I. \\
\hline B5 & 12.74 & 33.33 & 1.69 \\
ED3 & 11.74 & 33.33 & 1.68 \\
ED6 & 12.50 & 28.57 & 1.58 \\
ED9 & 13.18 & 28.57 & 1.58 \\
ED12 & 15.01 & 23.81 & 1.51 \\
ED15 & 15.74 & 23.81 & 1.52 \\
\hline
\end{tabular}

The specific fuel consumption curves of the engine are shown in figure 2c. In this figure, it is noticed a tendency of increase in consumption values when the ethanol content is incremented in the ED mixture, except when the engine used ED3 because the lower fuel consumption values were found. With ED3 the lowest value was 199.15g $\mathrm{kWh}^{-1}$ at $1400 \mathrm{rpm}$, while the highest consumption values were obtained using the ED15, reaching $247.36 \mathrm{~g} \mathrm{kWh}^{-1}$ at 2000rpm.

Results indicated that for all the fuels used, the lowest specific fuel consumption was obtained between 1400rpm and 1600rpm, which is the same speed range where the maximum torque values were found. For the specific fuel consumption (Table 2), it was found that when compared with B5, the ED3 had a reduction of $5.92 \%$ on consumption. With this mixture, it was noticed the highest fuel economy. The values obtained with B5, ED6, and ED12, had no statistical difference. Although with ED15, the increase was $3.77 \%$ compared to B5.

In experiments conducted by RAKOPOULOS et al. (2008), the authors reported an increase in specific fuel consumption by increasing the percentage of ethanol in diesel oil in turbocharged engines using ED5 and ED10. According to HANSEN et al. (2001), using ED10 in tractors and self-propelled grain harvester engines, the fuel consumption increased by 4 to $5 \%$, in relation to diesel oil.

\section{CONCLUSION}

The ethanol in diesel oil S500 (B5) may be used as an alternative fuel for agricultural tractor engines, without presenting great changes in the performance, since the ethanol content is at low percentages, up to $12 \%$.

It can be considered that the best results were found when using ED3, since this fuel was 
obtained with the lowest consumption values, without providing difference in the values of torque and power of the engine when compared with B5.

There was an increase in engine torque reserve when the ethanol content in B5 was higher; however, the result did not mean a benefit in engine performance since this increase was due to a decrease in engine reserve speed, also reducing the elasticity index.

\section{ACKNOWLEDGEMENTS}

The authors are grateful to the Coordenação de Aperfeiçoamento de Pessoal de Nível Superior (CAPES) for financial support. Also to the Conselho Nacional de Desenvolvimento Científico e Tecnológico (CNPq) for research productivity scholarship of the second author.

\section{REFERENCES}

AGARWAL, A. Biofuels (alcohols and biodiesel) applications as fuels for internal combustion engines. Progress in Energy and Combustion Science, v.33, n.3, p.233-271, Jun. 2007. Available from: $<$ http://www.sciencedirect.com/science/article/pii/ S0360128506000384>. Accessed: Nov. 10, 2014. doi: 10.1016/j. pecs.2006.08.003.

CHEN, Z.Q. et al. Physical-chemical properties of ethanolDiesel blend fuel and its effect on the performance and emissions of a turbocharged Diesel engine. International Journal of Automotive Technology, v.10, n.3, p.297-303, Jun. 2009. Available from: $\quad<$ http://link.springer.com/article/10.1007\%2 Fs12239-009-0034-0>. Accessed: Dec. 10, 2014. doi: 10.1007/ s12239-009-0034-0.

HANSEN, A.C. et al. On-farm evaluation of Diesel fuel oxygenated with ethanol. ASAE Technical paper 01-6173, 2001. Available from: <http://age-web.age.uiuc.edu/faculty/ach/ediesel/ Publications/onfarm016173.pdf>. Accessed: Sept. 16, 2014.

HANSEN, A.C. et al. Ethanol-Diesel fuel blends - a review. Bioresource Technology, v.96, n.3, p.277-285, Feb. 2005. Available from: $<$ http://www.sciencedirect.com/science/article/pii/ S0960852404001488>. Accessed: Oct. 13, 2014. doi: 10.1016/j. biortech.2004.04.007.

KASS, M.D. et. al. Emissions from a 5.9 liter Diesel engine fueled with ethanol Diesel blends. SAE Technical paper 200101-2018, 2001. Available from: <http://papers.sae.org/2001-012018>. Accessed: Sept. 16, 2014.doi: 10.4271/2001-01-2018.

KWANCHAREON, P. et al. Solubility of a Diesel-biodieselethanol blend, its fuel properties, and its emission characteristics from Diesel engine. Fuel, v.86, n.7-8, p.1053-1061, May 2007. Available from: $<$ http://www.sciencedirect.com/science/article/pii/ S0016236106003899>. Accessed: Sept. 26, 2014. doi: 10.1016/j. fuel.2006.09.034.

LAPUERTA, M. et al. Effect of ethanol on blending stability and Diesel engine emissions. Energy \& Fuels, v.23, n.9, p.4343-4354, Jul. 2009. Available from: <http://pubs.acs.org/doi/pdf/10.1021/ ef900448m>. Accessed: Oct.21, 2014. doi: 10.1021/ef900448m.

LAPUERTA, M. et al. Stability of Diesel-bioethanol blends for use in Diesel engines. Fuel, v.86, n.10-11, p.1351-1367, Jul-Aug. 2007. Available from: <http://www.sciencedirect.com/science/ article/pii/S0016236106004819>. Accessed: Sept. 26, 2014. doi: 10.1016/j.fuel.2006.11.042.

LI, D. et al. Physico-chemical properties of ethanol-Diesel blend fuel and its effect on performance and emissions of Diesel engines. Renewable Energy, v.30, n.6, p.967-976, May, 2005. Available from: $<$ http://www.sciencedirect.com/science/article/pii/ S0960148104003039>. Accessed: Oct. 13, 2014. doi: 10.1016/j. renene.2004.07.010.

MÁRQUEZ, L. Tractores agrícolas: tecnología y utilización. Madrid: B\&H Grupo Editorial, 2012. 844p.

RAHIMI, H. et al. Diesterol: an environment-friendly IC engine fuel. Renewable Energy, v.34, n.1, p.335-342, Jan. 2009. Available from: $<$ http://www.sciencedirect.com/science/article/pii/ S0960148108001389>. Accessed: Nov. 12, 2014. doi: 10.1016/j. renene.2008.04.031.

RAKOPOULOS, D.C. et al. Effect of ethanol-Diesel fuel blends on the performance and emissions of heavy duty DI Diesel engine. Energy Conversion and Manage, v.49, n.11, p.3155-3162, Nov. 2008. Available from: <http://www.sciencedirect.com/science/ article/pii/S0196890408002227>. Accessed: Dec. 10, 2014. doi: 10.1016/j.enconman.2008.05.023.

RIBEIRO, N.M. et al. The role of additives for Diesel and Diesel blended (ethanol or biodiesel) fuels: a review. Energy \& Fuels, v.21, n.4, p.2433-2445, May 2007. Available from: $<$ http://pubs. acs.org/doi/abs/10.1021/ef070060r>. Accessed: Oct. 21, 2014. doi: 10.1021/ef070060r.

SHADIDI, B. et al. Experimental investigation of the tractor engine performance using diesohol. Applied Energy, v.114, p.874-879, Feb. 2014. Available from: $<$ http://www.sciencedirect. com/science/article/pii/S0306261913005187>. Accessed: Oct. 21, 2014. doi: 10.1016/j.apenergy.2013.06.011.

TORRES-JIMENEZ, E. et al. Physical and chemical properties of etanol-Diesel fuel blends. Fuel, v.90, n.2, p.795-802, Feb. 2011. Available from: $<$ http://www.sciencedirect.com/science/article/pii/ S0016236110005168>. Accessed: Oct. 21, 2014. doi: 10.1016/j. fuel.2010.09.045. 